1 Childhood and Celebrity

2 Edited by

3 Jane O'Connor and John Mercer 
$1 \quad$ First published 2017

2 by Routledge

32 Park Square, Milton Park, Abingdon, Oxon OX14 4RN

4 and by Routledge

5711 Third Avenue, New York, NY 10017

6 Routledge is an imprint of the Taylor \& Francis Group, an informa business

7 C 2017 selection and editorial matter, John Mercer and Jane O'Connor; individual chapters, the 8 contributors.

9 The right of John Mercer and Jane O'Connor to be identified as the authors of the editorial material,

10 and of the authors for their individual chapters, has been asserted in accordance with sections 77 and 78

11 of the Copyright, Designs and Patents Act 1988.

12 All rights reserved. No part of this book may be reprinted or reproduced or utilised in any form or by any electronic, mechanical, or other means, now known or hereafter invented, including photocopying

14 and recording, or in any information storage or retrieval system, without permission in writing from the publishers.

Trademark notice: Product or corporate names may be trademarks or registered trademarks, and are used only for identification and explanation without intent to infringe.

19 A catalogue record for this book is available from the British Library. 
1 A catalogue record for this title has been requested

2 ISBN: 978-1-138-85527-4 (hbk)

3 ISBN: 978-1-138-85529-8 (pbk)

4 ISBN: 978-1-315-72043-2 (ebk)

5 Typeset in Bembo

6 by Out of House Publishing 


\section{Macaulay Culkin and child stardom in the 1990s}

3 Holly Chard

4 Macaulay Culkin was one of the most famous and highly paid child stars in the

5 history of Hollywood cinema. He secured global fame through the international

6 success of Home Alone (Columbus 1990), one of the highest-grossing comedies of all

7 time. A major beneficiary of the US film industry's increased investment in family

8 entertainment during the early 1990s, he could command a salary of \$5-8 million per

9 movie and attracted extensive attention from the American press. Culkin built his

10 career and star 'brand' on an image that combined modern precocity with

11 conventionally 'cute' looks. Much previous scholarship on child stars has focused primarily on the cultural dimensions of child stardom or analysis of children's performances on-screen. Hollywood stardom is not simply a cultural phenomenon, however. It is inextricably bound to the commerce of cinema. This chapter explores how Culkin's career was contingent on wider trends in the American media industries during the early 1990s, reflecting on how his fame and star image were used to sell films and a range of other products. Using a historical methodology, this chapter explores interactions between commercial and cultural facets of Culkin's stardom. An extensive survey of primary materials, from the period 1990-1995, including 
newspapers, magazines and film industry trade journals, forms the basis for this evaluation of the child star's career.

Star images, as Richard Dyer has persuasively argued, can resolve or expose ideological contradictions $(1979,1986)$. The ‘structured polysemy' (Dyer 1979 ${ }^{\text {BIB-010 }}$, p. 3) of Culkin's star image was constructed through, and sustained by, various media texts. Through analysis of media commentary on Culkin's attempts to move away from his Home Alone image, this chapter reflects on the conflicts that arise from competing claims over a child star's image. Child stars, observes Jane O'Connor, are often called upon to provide 'an idealised image of childhood', which can be based on 'an adult's ideal of what children should be like or a child's ideal of what they aspire to be like' (2008, p. 64). These notions of childhood are culturally constructed and therefore bound to particular historical contexts. 'As social constructions of childhood have shifted over time,' notes O'Connor, 'so have the requirements of child stars' (2011, p. 285). Examining responses to Culkin's stardom in newspapers and magazines, this chapter considers the tensions that can be created when trying to cater for diverse, sometimes conflicting, visions of childhood.

\section{Culkin's star image: the cute and the cool}

Macaulay Culkin's rise to stardom coincided with Hollywood's renewed efforts to court a family audience. During the early 1990s, as Robert C. Allen observes, a range 
1 of cultural and economic factors fuelled the film and media industries' increased

2 investment in movies and television shows aimed at a cross-generational audience.

3 Family-oriented films were ideally suited to take advantage of the maturing home

4 video market in the United States and Europe, particularly as the market shifted

5 towards a sell-through model (Allen $1999^{\mathrm{BIB}-001}$, pp. 112-13). The extensive and

6 highly lucrative sell-through campaigns for movies such as Disney's The Little

$7 \quad$ Mermaid (Clements and Musker 1989) and 20th Century Fox's Home Alone

8 demonstrated the substantial profit margins that successful family movies could

9 generate on video. Family films also helped Hollywood to counter claims, made by

10 conservative and Christian groups, that the film industry was not 'family friendly'

11 (Allen $1999^{\mathrm{BIB}-001}$, p. 115). In addition to being ideally positioned to take advantage of

12 increased expenditure on family and child-oriented films, Culkin's association with

13 the genre helped him to develop a clearly defined 'brand'. As McDonald notes,

14 'generic conventions contribute to the formation of strongly identifiable and saleable

15 identities' for Hollywood stars (2013, p. 31). Journalists and film industry personnel often referred to Culkin's 'natural' acting talent (Gliatto $1990^{\mathrm{BIB}-019}$, p. 130) and his ability to deliver 'the real thing' (Archerd $1993^{\text {BIB-003 }) . ~ T h i s ~ f o c u s ~ o n ~ t h e ~ b o y ' s ~ i n n a t e ~ a b i l i t y ~ w a s ~ c o n s i s t e n t ~ w i t h ~ a ~}$ cultural tendency to judge child actors' performances on their authenticity and 
1 'innocence', rather than in terms of the level of craft and expertise involved (Lury

$2 \quad 2010^{\mathrm{BIB}-033}$, p. 156). It was little coincidence that Culkin's blond hair, blue eyes, pale

3 skin, rosy cheeks and pouty lips conformed to longstanding (white American) ideals

4 of innocence and adorableness. This culturally enshrined ideal was encapsulated in

5 many of the images of the child that circulated during the early part of his career. In

6 Culkin's first film, the Burt Lancaster vehicle Rocket Gibraltar (Petrie 1988),

7 numerous shots of the boy's face are lit and framed to accentuate his distinctive facial

8 features. This focus on the child prompted People magazine's reviewer to note that

9 the director Daniel Petrie 'seems unable to keep the camera off Culkin' (Travers

$101988^{\mathrm{BIB}-054}$, p. 27). In the 1989 family comedy Uncle Buck (John Hughes 1989),

11 Culkin's cuteness was offset by precocity and an ability to comically undermine

12 adults through his observations, for instance in the rapid-fire dialogue his character,

13 Miles, exchanges with his uncle (played by John Candy). It was this "brand of angelic

14 brattiness', as New York magazine's Stephen J. Dubner described it, that helped

15 Culkin secure the lead in Home Alone (1993 ${ }^{\mathrm{BIB}-009}$; p. 56).

16 The character of Kevin McCallister in Home Alone combined a pre-teen

17 child's emotional vulnerability and naivety with resourcefulness and cunning. The

18 image of contemporary childhood that Culkin embodied in the movie was consistent

19 with a wider cultural trend, observed by Gary Cross, whereby "the cute child is 
1 naturally a little naughty but always nice, radiating not a naive look of youthful

2 beauty but energy, spunk and friskiness' (2004, p. 44). The cute child's inherent

3 goodness and adorable good looks allow for the pushing of the boundaries of

4 acceptable behaviour. This interplay between what Cross terms 'the cute and the cool'

5 (ibid.) was not only deployed widely in Culkin's film roles during the early 1990s, it

6 also formed the foundation of his star image, underpinning representations of the boy

7 outside of his movies. Moreover, numerous companies attempted to harness this

8 modern image of childhood for commercial reasons. Of course, as McDonald

9 suggests, 'Hollywood stardom cannot simply be regarded as the major studios foisting

10 representations on a compliant public'; rather, 'audiences play their part in forming

11 this market of identities' (2013, p. 39). By purchasing cinema tickets, videos and

12 various consumer products, audiences anointed Macaulay Culkin 'America's child star' (Gliatto $1990^{\mathrm{BIB}-019}$, p. 130).

\section{Wider commercial uses of Culkin's image}

During the early 1990s, tie-in deals with a range of corporations, particularly manufacturers of toys and food, became a significant revenue stream and a source of additional publicity for the major Hollywood studios. The highly orchestrated merchandising and tie-in campaign for Home Alone 2 (Columbus, 1992) demonstrated the increasingly sophisticated methods that companies were using to 
target a pre-teen demographic. The movie itself contained a number of prominent product placements, including Coca-Cola and American Airlines. The most controversial aspect of Home Alone 2's product placement strategy, however, was the way in which toys were incorporated into the narrative of the film. In a large number of scenes, Kevin/Culkin is shown using a Talkboy cassette recorder. Not only did such product placements capitalise on children's familiarity with Culkin as a celebrity, they also built on the affective relationship that children had with Home Alone's Kevin McCallister, through the deployment of what Gary Cross calls 'play narratives' (1997 ${ }^{\mathrm{BIB}-007}$, p. 107). While he may not have been fully aware of his commercial role, Culkin was nonetheless implicated in the strategy of "enticing 6year-olds to covet costly toys by putting the eye-catching devices in the hands of film heroes' (Horovitz 1992 ${ }^{\text {BIB-025 }}$ ). Although Culkin's parents attempted to limit the ways in which their son's image could be used (Busch $1992^{\text {BIB-005 }}$ ), companies produced around eighty Home Alone 2 products, including toys, books, video-games and apparel, many of which featured the boy's face. While these tie-ins were financially profitable for the Culkin family (Evans $1992^{\text {BIB-015 }}$, p. 50), the circulation of the Macaulay Culkin image via the film's promotional campaign and merchandise lines reinforced the connection between his star image and his Home Alone character. 
2 showing 'renewed interest in salvaging star power as a marketing tool' (Elliott 1992,

3 p. D5). With marketing strategies focused on adding 'values' to brands, in a bid to

4 influence consumers' feelings, celebrity endorsements offered a potentially efficient

5 way of transferring additional meanings to a product. Although advertising of this

6 kind had increased during the 1980s, partly due to deregulation of the television

7 industry, the use of celebrity endorsements to sell products to children came under

8 considerable scrutiny in the early Nineties. As a major celebrity with a young fan

9 base, Culkin was an ideal spokesman, and several major brands, including Pepsi and

10 Reebok, approached his managers with endorsement deals (Busch $1992^{\text {BIB-005 }}$ ). In

11 1992, Culkin signed a deal to endorse Sprite soda, which was reportedly worth at least

\$2 million (Rosato $1992^{\mathrm{BIB}-045}$, p. 1B). In the wake of the deal, Culkin allegedly stated of Sprite: 'I'm not crazy about the stuff. But money is money' (Newsweek 1992 ${ }^{\text {BIB-038, }}$ p. 23). The American press seized on this comment as an example of the child star's preoccupation with money and his growing cynicism. Based on the campaign that followed, Coca-Cola seemed aware of the need to mitigate the negative press coverage of the deal and criticisms of their use of Culkin's fame to sell sugary drinks to children. 
Culkin's Sprite television commercial appears to have been devised to deflect

2 criticism, by playing with notions of authenticity and audience 'knowingness'. The

3 advertisement shows Macaulay Culkin on a soundstage telling a girl that he is 'an

4 actor'. He then knocks down a set and points out that her parents are extras. After

5 offering her a Sprite he explains: 'It's all an illusion. The only thing that isn't fake is

6 this and us,' whereupon the girl becomes a cardboard cutout. The Sprite commercial's

7 ironic stance towards authenticity and overt deconstruction of its own premise, argues

8 Carolyn Hicks, reflects a more general trend towards 'anti-advertising' (1996, pp. 79

9 82). Through acknowledgement of the artifice of 'Macaulay Culkin' one of the

10 presumed foundations of celebrity endorsement, 'credibility' (McCracken 2005 $5^{\mathrm{BIB}-035}$,

11 pp. 98-9), is seemingly undermined. By openly acknowledging their efforts to manipulate consumers into buying their product, asserts Hicks, Coca-Cola sought to appeal to media-savvy and cynical members of 'Generation X' (1996). However, given Culkin's central role and the commercial's ties to Home Alone 2, teenagers and young adults were clearly not the primary target audience of the campaign. When viewed in this light, the Sprite commercial appears to be a playful attempt by CocaCola to argue that pre-teen children are also savvy enough to see through the artifice of advertising, television and movies. The approach may not have been sufficient to allay many parents' and media commentators' ethical concerns about Sprite's efforts 
1 to exploit Culkin's status as a pre-teen role model. Rather, the promotional strategy

2 demonstrated the lengths that corporations would go to in order to target young

3 consumers.

4 The limitations of Culkin's star image

5 Although the strength of Culkin's identification with his Home Alone persona and the

6 family film was commercially advantageous, in the case of My Girl (Zieff 1991) and

7 The Good Son (Ruben 1993) his presence in marketing materials and on-screen had

8 significant consequences for the movies' reception. Following the success of Home

9 Alone, studios were keen to capitalise on Culkin's popularity with audiences and the publicity that this celebrity status garnered. On this basis, Columbia agreed to pay $\$ 1$ million for the boy's participation in My Girl. Seeking to justify this substantial expense, the producer of My Girl, David Friendly, focused on the child's apparent uniqueness. ‘A Macaulay Culkin doesn’t come along very often,' Friendly asserted. ‘I think it would be a mistake to think there are a lot of 10-year-olds who can do what he does' (Gliatto $1990^{\mathrm{BIB}-019}$, p. 130). After making this investment in the child star, Friendly and Columbia Pictures clearly felt under pressure to capitalise on the audience's recognition of Culkin and his popularity with family audiences. Rather than focusing on the film's adult stars Dan Aykroyd and Jamie Lee Curtis, My Girl's poster instead showed Anna Chlumsky and Macaulay Culkin giggling cutely for the 
1 camera. Similarly, the trailer emphasised the comedy within the film and the

2 relationship between the two children. Audiences' expectations were undoubtedly

3 shaped by this use of Culkin's image in publicity materials. Stars, as John Ellis notes,

4 'provide a foreknowledge of the fiction' (1982, p. 91). Thus, the studio's

5 foregrounding of Culkin and selective representation of My Girl suggested that the

6 movie would be a family-friendly comedy, consistent with his previous work.

The reception of My Girl demonstrated the risks of building an advertising campaign around a child star whose primary fan base consists of pre-teens. Although

9 publicity materials sold My Girl as a light-hearted family film, the movie itself was

10 thematically mature and more suitable for older children. Once scene in particular, which depicted Macaulay Culkin's character lying dead in an open casket after being killed by a swarm of bees, became a focal point for criticisms of the movie. Parents and critics accused Columbia of misleading audiences and exposing young children to potentially distressing content (James $1991^{\text {BIB-026 }}$, pp. H11-12). Reacting to criticisms of their commercial strategy, the studio announced that child psychologists and teachers had given the movie positive reviews (James $1991^{\text {BIB-026 }}$, p. H12). Acting as an unofficial spokesman for 'the attitudes of savvy 90s children', suggested The New York Times' Caryn James, Culkin stated that anyone upset by his character's death 
surrounding My Girl formed part of a wider debate concerning what was appropriate subject matter for a family film and whether it was appropriate for studios to build children's awareness of more mature movies through the use of a child star. A slightly different set of concerns underpinned press coverage of Culkin's involvement in The Good Son, an R-rated thriller. The role of 'bad seed' Henry was what Richard Dyer terms a 'problematic fit' (1979 ${ }^{\text {BIB-010 }}$, pp. 146-9) for Culkin's star image. A number of senior studio personnel, including The Good Son's original producer Lawrence Mark, allegedly objected to the boy's casting in the central role because they felt his Home Alone persona would make it difficult for audiences to accept him in the role of a sociopathic child (Eller $1992^{\text {BIB-012 }}$, p. 1). Similarly, Variety's reviewer predicted 'complaints about casting [a] childhood icon as the embodiment of evil' (Lowry 1993 ${ }^{\text {BIB-032 }}$ ). Anticipating criticisms of the use of Culkin's image in the advertising campaign for The Good Son, executive vice president of 20th Century Fox, Tom Sherak, explained to Variety, 'We do not want this to look like a comedy or family fare' (O'Steen $1993^{\text {BIB-041 }}$, p. 11). The studio made a concerted effort to market the film as a thriller and, consistent with Hollywood's standpoint in this period, argued that parents should pay attention to the R-rating (O’Steen $1993^{\text {BIB-041 }}$, p.11). Culkin's involvement in The Good Son was not necessarily detrimental to its commercial prospects, however. At least one report 
suggested that a large number of parents had agreed to accompany their pre-teen children to the cinema so that they could watch the movie (Smith $1993^{\mathrm{BIB}-047}$ ), suggesting that the boy's involvement had widened the film's audience.

The reception of The Good Son was clearly influenced by what Dyer describes as 'a clash between two complex sign clusters, the star as image and the character as otherwise constructed' (1979, p. 147). Reactions to Culkin's involvement in the movie focused primarily on whether he was an appropriate choice for the role of Henry. In some cases, his lack of suitability for the role was framed merely in terms of his limited ability as a dramatic actor. The Los Angeles Times' Kenneth Turan suggested that, despite Culkin's best efforts, he 'comes off more sullen and pouty than evil' and 'can't overcome the fact that he is simply miscast' (1993). A number of reviewers proposed that Culkin's star image was so firmly established in audience members' minds that it was difficult to disassociate the character of Henry from the child star's Home Alone persona. The Hollywood Reporter's David Kronke, for instance, described the film as 'inadvertent camp' and argued that the character of Henry 'pretty much apes Culkin's behaviour in the Home Alone films, except in those it was considered cute' (1993). Similarly, Variety's Brian Lowry argued that Culkin's performance relied on 'the same detachment as the Home Alone movies' (1993, p. 41). Such appraisals hinted at an uncomfortable relationship between the comic, 
1 slapstick violence of the Home Alone films and the malicious, homicidal actions of

2 Henry in The Good Son. They also alluded to a potentially dark side to the character

3 traits that Culkin embodied as Kevin in Home Alone. Ultimately, these reviews

4 indicated that Culkin's cuteness, when presented alongside the mixture of comedy and

5 sentiment that characterised movies like Home Alone, was key to the popularity of his

6 star image. As a consequence, any attempts to move beyond his established image

$7 \quad$ seemed unlikely to succeed.

Suggesting a retreat from more challenging subject matter, all of Culkin's last three film roles as a child star, Getting Even With Dad (Deutch 1994), The

$10 \quad$ Pagemaster (Johnston and Hunt 1994) and Richie Rich (Petrie 1994), traded heavily on his Home Alone persona. As the Los Angeles Times' Lynn Smith bluntly stated, ‘Anyone who was hoping that by now Macaulay Culkin would have outgrown the Home Alone character can forget it' (1994). The centrality of cuteness to Culkin's image and his appeal to audiences became increasingly evident in these films. Despite the studios' attempts to conceal changes to Culkin's physical appearance, by casting tall adults in central roles and strategic use of editing and camera angles, the onset of puberty undermined this fundamental element of his star image and his appeal to audiences. The inclusion of somewhat awkward references to puberty and sex in both 
1 to address Culkin's shift from pre-teen to adolescent. Getting Even With Dad, The

2 Pagemaster and Richie Rich also struggled to reconcile the growing tensions between

3 Culkin's established on-screen persona and his rapidly changing off-screen image.

4 Construction and destruction of Culkin's star image

5 The extensive coverage of Macaulay Culkin's career in newspapers and glossy

6 magazines during the early 1990s not only helped to sustain the child star's career, but

7 also stimulated sales of publications to a public eager for more details of his off-

8 screen life. In many respects, press coverage of Culkin's life and career conformed to

9 the 'general image of stardom' identified by Richard Dyer, which portrays 'a version of the American dream, organised around the themes of consumption, success and ordinariness' (1979 ${ }^{\mathrm{BIB}-010}$, p. 39). Initially, articles and images in a wide range of publications focused on the message that Culkin was a 'normal' child, who lived an ordinary life, despite the fact that he had been a professional actor since an early age. Stories of Culkin's ascent to fame and fortune were consistent with established myths of success and the American dream. Articles often noted that Culkin had grown up sharing a bedroom with six siblings, while his parents struggled to make ends meet via part-time work. Praise for Culkin's work ethic and ability to cope with the responsibility of being the star of Home Alone were seemingly compatible with this narrative of individual success through hard work. People magazine, for example, 
1 highlighted Catherine O'Hara's observation that, 'He's a darling little guy who has

2 been acting since he was four, so he's very professional' (Allis $1990^{\text {BIB-002 }}$, p. 92). At

3 the same time, however, the average American childhood was distanced from the

4 world of work, creating an underlying tension between his supposed ordinariness and

5 his professionalism. Much of the publicity that followed sought to hold these elements

6 of Culkin's star image together.

The tension between Culkin's on-screen 'everykid' persona and his status as a millionaire celebrity was evident in many of the articles written about Culkin during

9 the early 1990s. In an attempt to confirm Culkin's normality, a cover article on 'The

10 World's Richest Kids' in People claimed that the child star was given a '\$5 a week

11 allowance' and 'doesn't get to flaunt' his money (Green $1992^{\text {BIB-020 }}$, p. 116). At the same time, a large number of articles focused their attention on Culkin's exceptional wealth and celebrity lifestyle. Following Home Alone's box-office success, Time magazine proclaimed, 'Now whatever Mack wants, Mack gets - video games, trips to Florida, multimillion dollar movie and merchandising deals' (Chua-Eoan 1991 ${ }^{\text {BIB-006, }}$ p. 82). This perspective was also offered in the glossy magazine coverage of Culkin's brief, chaste relationship with pre-teen model and actress Laura Bundy, which focused on the boy's wealth and the glamorous aspects of his increasingly atypical childhood. Photographs of the cute 'couple' attending various events alongside adult 
1 celebrities, such as a 'Manhattan Christmas bash', and reports of grand 'romantic'

2 gestures, such as trips to Bundy's home in Kentucky to celebrate Halloween,

3 limousine rides and various gifts, highlighted Culkin's wealth and the children's

4 distance from the domestic sphere (Lipton $1992^{\text {BIB-031 }}$, p. 58; Fink $1992^{\text {BIB-016 }}$, p. 45).

5 Thus, reports of Culkin's fame and commercial influence soon started to erode any

6 impression of his normality.

Film stars' identities, as Marshall notes, 'are invested with conceptions of

8 freedom, independence and individuality' (1997, p. 85). Culkin clearly demonstrated

9 these traits both on- and off-screen. These values are incompatible, however, with the

10 notion of children as dependent on adults and with idealised images of children as

11 untainted by commerce. Moreover, Culkin's status as a minor amplified the seemingly contradictory attitudes expressed towards celebrities' lifestyles, which, as Karen Sternheimer observes, 'reveal a central contradiction within American culture: the coinciding desire for plenty and the lingering value placed on self-restraint' (2011, p. 12). As Culkin's fame and commercial status increased, articles focusing on his personal life became more critical of what was presented as excessive consumption and freedom, symptomatic of the lack of control that adults had over the young millionaire. Following an alleged boast by Culkin that he could watch as much television as he wanted, People magazine published several letters condemning the 
1 boy and his parents. 'It's easy to see who is in control in that house,' proclaimed one

2 incredulous reader (Peronne $1992^{\mathrm{BIB}-042}$, p. 4). 'He used to be a precocious darling,'

3 another reader declared; 'He has now become a pompous, spoiled brat' (Kochiss

4

consternation expressed in these letters arguably alluded to a more general anxiety about submissive parenting and American children's excessive exposure to television.

The perils of child stardom also became a subtext to press coverage of Culkin's friendship with Michael Jackson. Although US media outlets reported on Culkin's association with several former child stars, including Elizabeth Taylor, Liza Minnelli and Brooke Shields, it was Culkin's close friendship with Jackson that became a particular source of fascination during the early 1990s. Stories of shopping sprees in Toys R Us, a vacation in Bermuda, visits to theme parks and numerous trips to Jackson's Neverland ranch provided plenty of material for glossy magazines and tabloid newspapers. Although publications often acknowledged the age gap between Culkin and thirty-something Jackson, they typically presented the relationship between the two as innocent and childlike. During this period, suggests Amy Billone, 'Jackson's attachment to the character of Peter Pan and his celebration of eternal childhood' allowed him to sustain the fame he first experienced as a child star (2012, p. 46). From August 1993 onwards, following highly publicised allegations that 
1 Jackson had abused 13-year-old Evan Chandler, the press became more cautious in

2 their reporting on the pop star's friendship with Culkin. Despite Culkin's public

3 declarations that nothing inappropriate had occurred during his 'sleepovers' at

4 Jackson's Neverland ranch, the mere spectre of child abuse cast Jackson's relationship

5 with Culkin in a new light. The press also began to present Jackson's lifestyle as a

6 warning of what the future could hold for Culkin if steps were not taken to lessen the

$7 \quad$ impact of his fame and fortune.

Given the press' interest in Michael Jackson's dysfunctional childhood and relationship with his father, it was perhaps unsurprising when Macaulay Culkin's father came under increased scrutiny. Christopher 'Kit' Culkin was the driving force behind his son's career and the Hollywood trade press often referred to his reputation as a tough negotiator. From 1989 onwards, Kit Culkin managed his son's career fulltime and was therefore entitled to ten per cent of his earnings (Schneider 1993 $3^{\text {BIB-046, }}$ p. 48). In November 1993, Variety published a major story entitled 'Kit Culkin Orchestrates Nutcracker Nightmare', which accused Culkin's father of creative interference and of using his child as a bargaining tool (Fleming $1993^{\text {BIB-017 }}$, p. 2). Cover stories in New York magazine and People followed, bringing accusations of Kit Culkin's controlling nature and alleged exploitation of his son to a wider audience 
1 negative impact on industry perceptions of the child star. People's Karen Schneider,

2 for instance, suggested, “No one, no matter how angry, blames Macaulay himself for

3 the backlash' (Schneider $1993^{\text {BIB-046 }}$, p. 46). Through their evocation of the image of

4 the pushy stage parent, such reports seemed to endear the child star more to adults.

5 Consequently, Kit Culkin was increasingly viewed by audiences as, in the words of

6 one People reader, 'an overzealous control freak who is trying to live out his own lost

7 celebrity through his son' (Thompson $1994^{\mathrm{BIB}-053}$, p. 13).

8 An 'ageing child star'

9 While the decline of Culkin's career seems to fit neatly within the narrative of 'the curse of the child star', it would be a mistake to view this trajectory as preordained. Culkin was able to build a 'brand' through a reliance on what Barry King has dubbed 'personification' whereby 'the range of the actor is limited to parts consonant with his or her personality' (1985, p. 30). This approach relied heavily on attempts to regulate Culkin's image by his management team and the studios. As has been illustrated, his stardom was firmly tied to the family-film genre and a persona based on his character from Home Alone. This connection was reinforced via various efforts to utilise his star image and notoriety for commercial gain. While child stars had, to varying extents, been implicated in promoting conspicuous consumption in the past, Culkin's fame coincided with a growing interest in children as consumers and increases in 
1 specifically child-oriented marketing. Media commentators and, no doubt, parents

2 questioned the ethics of exploiting Culkin's notoriety and children's desire to emulate

3 his lifestyle, their concerns occurring against a backdrop of wider debates on

4 marketing to children. Negative responses to Culkin's role in endorsing products

$5 \quad$ hinted at anxieties concerning their influence over their own children and

6 corporations' attempts to shape children into consumers from an early age. In spite of

7 attempts to broaden Culkin's appeal and demonstrate his abilities as an actor, most

8 notably via The Good Son, separating the child star from his reputation as a performer

9 in family-friendly comedies proved to be a difficult enterprise.

10 Culkin later confirmed that pressures caused by his family life and his lack of

11 interest in making more family films were the primary drivers in his decision to

12 suspend his career as an actor in 1994. The failure to develop Macaulay Culkin's on-

13 screen persona, to accommodate shifts in his off-screen image or physical appearance,

14 was nonetheless a major factor in the decline of his childhood acting career. In a

15 review of Richie Rich, Culkin's last film as a child star, the Hollywood Reporter noted

16 that the 14-year-old was "finding [it] tough to still play "cute"" while "in the greasy

17 throes of adolescence' and was 'getting a tad long in the tooth for the role he was born to play' (1994). Similarly, Daily Variety's reviewer referred to his 'fading

19 superstardom' and attributed this decline primarily to his status as an 'aging child 


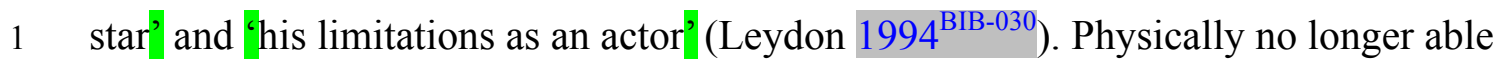

2 to offer the 'cute' image audiences had come to associate with 'Macaulay Culkin' and

3 his lack of developed acting skills meant that he was unable to meet the expectations

4 of critics, and the contradictions in his star image became increasingly exposed.

5 The 'myth of the curse of child stardom', argues O'Connor, serves to promote

6 "the idea of childhood as a private, family-oriented time of life separate from the adult

7 world of work and responsibility' (2008, p. 75). Early press coverage of Culkin's

8 career and off-screen life often attempted to reconcile this contradiction, no doubt to

9 the delight of Culkin's management team and publicists. As the 1990s wore on,

10 however, magazine and newspaper reports focused much more on the unusual aspects

11 of the boy's life and the dangers posed by his behaviour. The fascination with fallen

12 child stars, adds $\mathrm{O}^{\prime}$ Connor, can 'be seen as a reaction against the more generalised

13 fear that children today are becoming too powerful, too knowing, and are growing up

14 too fast' (ibid., p. 75). Through evocation of the concept of 'sheltered innocence',

15 argues Gary Cross, adults can convince themselves that threats to this ideal of

16 childhood originate from outside the home and the family (2004, p. 14). In this way,

17 reactions to Culkin's alleged misbehaviour provided an outlet for more general

18 anxieties about contemporary childhood. The powerful contradiction at the heart of

19 child stardom, however, is that while adult audiences express pity and hostility 
1 towards child stars, they are often complicit in the manufacture of these young

2 celebrities. 'Child stars are often perceived as melancholy, sacrificial figures,'

3 suggests Jacqueline Warwick, "with audiences lamenting the "normal" childhoods lost

4 even as they devour the manufactured childhoods offered' (2012, p. 252). As Culkin's

5 career illustrates, while they are often called upon to present idealised representations

6 of 'normal' childhood on-screen, due to their engagement in commercial and public

7 spheres, child stars will always struggle to conform to this image.

8 References

Allen, R.C., 1999. Home Alone Together: Hollywood and the family film. In: London: BFI, pp. 109-34.

Allis, T., 1990. Success Finds Catherine O’Hara. People, 24 December: 92.

Archerd, A., 1993. Just for Variety. Daily Variety, 24 September. Available from: LexisNexis Academic database [accessed 12 October 2015]. 
Busch, A., 1992. Culkin managers are a tough sell to advertisers. The Hollywood Reporter, 11 March. Available from: LexisNexis Academic database [accessed 12 October 2015].

Chua-Eoan, H., 1991. At Home, But Not Alone. Time, 9 December: 82-3.

Cross, G., 1997. Kids Stuff: Toys and the Changing World of American Childhood. Cambridge, MA: Harvard University Press.

BIB-008

Cross, G., 2004. The Cute and the Cool: Wondrous Innocence and Modern American Children s Culture. New York: Oxford University Press.

Dubner, S.J., 1993. My Art Belongs to Daddy. New York, 29 November: 52-7.

Dyer, R., 1979. Stars. London: British Film Institute.

BIB-011

Dyer, R., 1986. Heavenly Bodies: Film Stars and Society. New York: St Martin"s Press.

Eller, C., 1992. Culkin's dad sacks Mark, Daily Variety, 3 December 1.

Elliott, S., 1992. New Tactics On Celebrity Endorsement, The New York Times, 3 April: D5.

BIB-014

Ellis, J., 1982. Visible Fictions: Cinema, Television, Video. New York: Routledge.

Evans, G., 1992. At The Court of King Culkin. Daily Mail, 4 December: 50-1. 
Fleming, M., 1993. Kit Culkin Orchestrates Nutcracker Nightmare. Variety, 8 November: 2.

Getting Even With Dad, 1994. Film. Directed by Howard Deutch. USA: Metro-

4

BIB-019

6

BIB-020

BIB-021

9

BIB-022

BIB-023

BIB-024

14

BIB-025 Goldwyn-Mayer.

Gliatto, T., 1990. Running Away with the Box Office by Staying Home Alone. People, 17 December: 127-30.

Green, M., 1992. Silver Spoons. People, 5 October: 106-16.

Hicks, C., 1996. The only things that aren't fake are you, me and Sprite. Metro: Media \& Education Magazine, No. 106: 71-82.

Hollywood Reporter, 1994. Richie Rich. Hollywood Reporter, 21 December. Available from: LexisNexis Academic database [accessed 12 October 2015].

Home Alone, 1990. Film. Directed by Chris Columbus. USA: 20th Century Fox.

Home Alone 2: Lost in New York, 1992. Film. Directed by Chris Columbus. USA: 20th Century Fox.

Horovitz, B., 1992. New Twist in Tie-Ins: Home Alone 2 May Redefine Merchandising. Los Angeles Times, 12 November. Available from: http://articles.latimes.com/1992-11-12/business/fi-433_1_merchandisingempire [accessed 12 October 2015]. 
James, C., 1991. Reality Comes with the Popcorn. The New York Times, 1 December: H11-12.

King, B., 1985. Articulating Stardom. Screen, 26 (5): 27-51.

Kochiss, I., 1992. Mail: Macaulay Culkin. People, 14 December: 4.

BIB-029

Kronke, D., 1993. The Good Son. Hollywood Reporter, 20 September. Available from: LexisNexis Academic database [accessed 12 October 2015].

BIB-030

Leydon, J., 1994. Richie Rich. Daily Variety, 21 December. Available from: LexisNexis Academic database [accessed 12 October 2015].

Lipton, M., 1992. Up Front. People, 23 November: 58.

Lowry, B., 1993. The Good Son. Daily Variety, 20 September: 40-1.

Lury, K., 2010. The Child in Film: Tears, Fears and Fairy Tales. London: I.B. Tauris.

Marshall, P.D., 1997. Celebrity and Power: Fame in Contemporary Culture. Minneapolis: University of Minnesota Press.

McCracken, G., 2005. Culture and Consumption II: Markets, Meaning, and Brand Management. Bloomington: Indiana University Press.

BIB-036

McDonald, P., 2013. Hollywood Stardom. Malden: Wiley-Blackwell.

BIB-037

My Girl, 1991. Film. Directed by Howard Zieff. USA: Columbia Pictures.

BIB-038

Newsweek, 1992. Overheard. Newsweek, 30 March: 23.

BIB-039

O'Connor, J., 2008. The Cultural Significance of the Child Star. London: Routledge. 
O’Connor, J., 2011. From Jackie Coogan to Michael Jackson: what child stars can tell us about ideologies of childhood. Journal of Children and Media, 5 (3): 284 97.

O'Steen, K., 1993. Good Son sees rough marketing ride, Variety, 27 September: 11.

Peronne, M., 1992. Mail: Macaulay Culkin. People, 14 December: 4.

BIB-043

Richie Rich, 1994. Film. Directed by Donald Petrie. USA: Warner Bros. Family Entertainment.

Rocket Gibraltar, 1988. Film. Directed by Daniel Petrie. USA: Columbia Pictures.

Rosato, Donna, 1992. Culkin Pitches Sprite. USA Today, 12 March: 1B.

Schneider, K., 1993. Daddy Dearest. People, 13 December: 44⒐

Smith, L., 1993. Evil in The Good Son Seen As Good Clean Fun. Los Angeles Times,

7 October. Available from: http://articles.latimes.com/1993-10-07/news/ol42992_1_clean-fun [accessed 12 October 2015].

Smith, L., 1994. Macaulay Culkin's at Home in Getting Even. Los Angeles Times, 23 June. Available from: http://articles.latimes.com/1994-06-23/news/ol7456_1_macaulay-culkin [accessed 12 October 2015].

Sternheimer, K., 2011. Celebrity Culture and the American Dream: Stardom and Social Mobility. New York: Routledge.

The Good Son, 1993. Film. Directed by Joseph Ruben. USA: 20th Century Fox. 
The Little Mermaid, 1989. Film. Directed by Ron Clements and John Musker. USA: Walt Disney Pictures.

BIB-052

The Pagemaster, 1994. Film. Directed by Joe Johnston and Maurice Hunt. USA: 20th

4

BIB-053

BIB-054

BIB-055

9

BIB-056

BIB-057 Century Fox.

Thompson, V., 1994. Mail: Kit Culkin. People, 10 January: 13.

Travers, P., 1988. Rocket Gibraltar. People, 12 September: 27.

Turan, K., 1993. Are You Ready For Macaulay Culkin as Bad Seed? Los Angeles Times, 24 September. Available from: http://articles.latimes.com/1993-0924/entertainment/ca-38386_1_macaulay-culkin [accessed 12 October 2015].

Uncle Buck, 1989. Film. Directed by John Hughes. USA: Universal Pictures.

Warwick, J., 2012. You Cant Win, Child, but You Can th Get Out of the Game: Society, 35 (2): 241-259. 